\title{
Improvement of Papaya Seed Germination by Different Growth Regulator and Growing Media under Net House Condition
}

\author{
Amit Desai $^{1 *}$, Ashwin Trivedi ${ }^{2}$, Bharat Panchal $^{1}$ and Velji Desai ${ }^{1}$ \\ ${ }^{1}$ Department of Horticulture, B. A. College of Agriculture, Anand Agricultural University, \\ Anand-388 110, Gujarat, India \\ ${ }^{2}$ ICAR-Directorate of Medicinal and Aromatic Plant Research, Anand, Gujarat, India \\ *Corresponding author
}

\section{A B S T R A C T}

\section{Keywords \\ $\mathrm{GA}_{3}$, Cow urine, \\ Media, \\ Germination, \\ Papaya seedling. \\ Article Info \\ Accepted: \\ 14 July 2017 \\ Available Online: \\ 10 September 2017}

Seed germination is the most important aspect for raising the nursery for successful seedling production of Papaya. The present study was carried out to explore the effect of different growth promoter with growing media on seed germination of Papaya. (Carica papaya L.) cv. Madhubindu under net house condition. The seeds of papaya were treated with different concentrations of $\mathrm{GA}_{3}$ and cow urine and sowing in different growing Media's viz., Coco peat, Vermicompost and Soil. Highly significant different was observed between the treatments. The results showed that the treatment combinations $\mathrm{G}_{3} \mathrm{M}_{1}\left[\mathrm{GA}_{3}\right.$ @ $150 \mathrm{mg} / \mathrm{l}$ dipping for 12 hours and soil + cocopeat $(1: 1)]$ is significantly recorded highest germination percentage $(84.00 \%$ and $95.00 \%)$ at 10 and 20 DAS, respectively and also recorded significantly minimum number of days (8.33) required 50 per cent germination. Whereas, treatment combination $\mathrm{G}_{6} \mathrm{M}_{1}$ [cow urine $10 \%$ dipping for 18 hours and soil + cocopeat $(1: 1)$ ] recorded significantly the highest seed vigour index- I and II, dry weight of shoot and dry weight of root at 30 and 45 DAS. Similarly, the highest root: shoot ratio at 30 and 45 DAS and seed vigour index- II at 30 DAS was recorded in treatment combination $\mathrm{G}_{5} \mathrm{M}_{1}$ [cow urine $10 \%$ dipping for 12 hours and soil + cocopeat $(1: 1)]$.

\section{Introduction}

Papaya (Carica papaya L.) is $7^{\text {th }}$ important fruit crop of the country after Mango, Citrus, Banana, Apple, Guava and Sapota. The fruit is extensively grown in various states of India, mainly in Andhra Pradesh, Gujarat, Karnataka, Madhya Pradesh, Maharashtra, West Bengal, Chhattisgarh, Tamil Nadu, Assam, and Kerala. Seed germination in Papaya is very slow, erratic and also incomplete. The cost of Papaya seed is also high so increasing germination percentage and producing more vigour seedling is a challenge of Papaya grower. The slow germination of papaya seed is due to the presence of some inhibitors like phenolic compound. Seed treatment is required to promote seed germination and reduce the germination time with suitable growing media. Gibberellic acid $\left(\mathrm{GA}_{3}\right)$ can stimulate rapid stem and root growth, induce mitotic division in the leaves of some plants, and increase seed germination rate. Cow urine contains about $1.21 \% \quad \mathrm{~N}_{2}, 0.01 \% \quad \mathrm{P}_{2} \mathrm{O}_{5}$ and $1.35 \% \mathrm{~K}_{2} \mathrm{O}$ (Subramaniyam, 2005), and also 
contains physiologically active substances viz., growth regulators, nutrients (Kamalam and Rajappan, 1989) and trace elements (Munoz, 1988). Growing Media is a substrate that provides the required elements and physical support to the growing plants. All soils used for media are not always perfect for the germination of seeds and subsequent growth of seedling. Seed germinate in containers have limited volume of soil and nutrients. Media should also have good water holding capacity, drainage and other physical and chemical properties. So it is desirable to provide such soil media or mixture, which fulfills the requirements for maximum seed germination and better seedling growth. The seeds of papaya are enclosed within a gelatinous sarcotesta (aril, or outer seed coat which is formed from the outer integument.) which can prevent germination (Yahiro, 1979). Before sowing of seeds is soaking in water or water soluable endogenous hormones has been reported to promote the germination. The objective of the study was to increase the seed germination and physiological development of papaya seedlings through applying the growth regulator with different growing media.

\section{Materials and Methods}

Present investigation was conducted at Horticulture Research Farm, Anand Agricultural University, Anand, from JuneJuly during the year 2016. The experiment was laid out in a Completely Randomized Design (Factorial) with eighteen (18) treatment combinations and replicated thrice. Fully mature and healthy fruits of papaya cv. Madhubindu were collected. Seeds were extracted and shade drying till the seed were completely dried. These fresh seed were collected and subjected to different presowing treatments. The treatments comprised of three levels of $\mathrm{GA}_{3}$ and cow urine i.e. $\left(\mathrm{G}_{1}\right)$ $\mathrm{GA}_{3} @ 50 \mathrm{mg} / \mathrm{l}$ dipping for 12 hours, $\left(\mathrm{G}_{2}\right)$ $\mathrm{GA}_{3} @ 100 \mathrm{mg} / \mathrm{l}$ dipping for 12 hours, $\left(\mathrm{G}_{3}\right)$ -
$\mathrm{GA}_{3} @ 150 \mathrm{mg} / \mathrm{l}$ dipping for 12 hours, $\left(\mathrm{G}_{4}\right)$ cow urine $10 \%$ dipping for 6 hours, $\left(\mathrm{G}_{5}\right)$ - cow urine $10 \%$ dipping for 12 hours, $\left(\mathrm{G}_{6}\right)$ - cow urine $10 \%$ dipping for 18 hours as well as three levels of growing medias i.e. $\left(\mathrm{M}_{1}\right)$ - soil + cocopeat (1:1), $\left(\mathrm{M}_{2}\right)$ - soil + vermicompost $(1: 1)$ and $\left(\mathrm{M}_{3}\right)$ soil + vermicompost + cocopeat (1:1:1). Observations were recorded in respect to first germination from the date of sowing up to germination of the first seedling, germination percentage at 10 and 20 DAS by counting number of papaya seeds germinated out of total seed dibbled. Seed vigour index - I at 30 and 45 DAS (germination percentage $x$ length of seedlings), seed vigour index - II at 30 and 45 DAS (germination percentage $x$ total dry weight of seedling) and root: shoot ratio at 30 and 45 DAS by dividing dry weight of roots by dry weight of shoots of five randomly selected seedlings and its average value was calculated.

The recorded data were analyzed statistically using various techniques as described by Panse and Sukhatme (1985). The treatment means were compared with C.D. at 5 per cent level.

\section{Results and Discussion}

As per the results, the significant different was observed between the treatment on seed germination and seedling growth attributes.

\section{Effect of growth regulators on seed germination}

Treatments $\mathrm{G}_{3}\left(\mathrm{GA}_{3} @ 150 \mathrm{mg} / \mathrm{l}\right.$ dipping for 12 hours) significantly took the minimum days (7.55 and 9.44) for first germination and 50 per cent germination, respectively this results were supported by Kumawat et al., (2014) in papaya. This treatment also recorded significantly highest germination percentage (77\% and $87 \%$ at 10 and 20 DAS, respectively). Similar trends were also 
obtained by Deb et al., (2010). It might be due to $\mathrm{GA}_{3}$ helped in physically breaching, thereby removing physiological barriers associated with the impermeable seed coats that cause seed dormancy (Mayer and mayber 1963) (Table 1).

\section{Effect of growing media on seed germination}

Media $\mathrm{M}_{1}$ [soil + cocopeat (1:1)] significantly took the minimum days (7.55 and 9.05) required for first germination and 50 per cent germination, respectively as compared to rest of medias. Similar results were obtained by Kumawat et al., (2014) and Mandal et al., (2015) in papaya when they used cocopeat as ingredients of growing media. And also recorded significantly highest germination percentage $(77.89 \%$ and $88.28 \%$ ) at 10 and 20 DAS, respectively as compared to the rest of the Medias.

These results were in close agreement with Mandal et al., (2015) and Ramteke et al., (2015) in papaya when they used cocopeat as ingredients of growing media. It might be due to the media containing organic manures possess organic acid within them. Therefore, more available moisture and some acids may have helped in better germination of seeds (Bisla et al., 1984).

\section{Interaction effect of growth regulators and growing media on seed germination}

Interaction effect of $\mathrm{G}_{3} \mathrm{M}_{1}\left[\mathrm{GA}_{3} @ 150 \mathrm{mg} / \mathrm{l}\right.$ dipping for 12 hours and soil + cocopeat (1:1)] recorded significantly the minimum days (8.33) required for $50 \%$ germination as compared to rest of the combinations. Similar results were also obtained by Kumawat et al., (2014) in papaya. Treatment combination $\mathrm{G}_{3} \mathrm{M}_{1}$ also recorded significantly highest germination percentage $(84.00 \%$ and $95.00 \%)$ at 10 and 20 DAS, respectively as compared to rest of the combinations. Similar results were also obtained by Deb et al., (2010) and Kumawat et al., (2014) in papaya and Patil et al., (2012) in Rangpur lime. It might be due to $\mathrm{GA}_{3}$ acts on the embryo and causes synthesis of hydrolysing enzymes particularly amylase and protease and this hydrolysed food is utilized for grown of embryo and thereby enhanced the germination (Paleg, 1965) and retention of more water and air by media helped in quick and early enzymatic action for synthesis of metabolites for cell multiplication and also enhanced the breakdown of the seed coat resulting in the transformation of embryo into a seedling early enough (Hasan et al., 2010) which is helpful for increasing germination of seeds (Table 2).

\section{Effect of growth regulators on seedling growth attributes}

Treatments $\mathrm{G}_{6}$ (cow urine 10\% dipping for 18 hours) were recorded significantly the maximum seed vigour index- I. (1518 cm and $2868 \mathrm{~cm})$, seed vigour index- II (130 $\mathrm{g}$ and $216 \mathrm{~g})$ at 30 and 45 DAS, respectively as compared to rest of treatments. These results were in close agreement with Ambika et al., (2014) in cereals and Ambika and Balakrishnan (2015) in cluster bean. This treatment also recorded significantly maximum dry weight of shoot $(0.85 \mathrm{~g}$ and $1.45 \mathrm{~g})$, dry weight of root $(0.73 \mathrm{~g}$ and $1.18 \mathrm{~g})$ at 30 and 45 DAS, respectively as compared to rest of treatments. Whereas, the treatment $\mathrm{G}_{5}$ (cow urine $10 \%$ dipping for 12 hours) was recorded significantly the highest root: shoot ratio $(0.90 \mathrm{~g}$ and $0.91 \mathrm{~g})$ at 30 and $45 \mathrm{DAS}$, respectively as compared to rest of the treatments. These results were in close agreement with the results of Sutheesh et al., (2016) in sandal wood. It might be due to the cow urine was maintaining of high water content in cell, increased cell division and cell elongation which increased the germination and overall growth of the seedlings which may helped to increase seed vigour and dry weight of root and shoot of seedlings. 
Table.1 Effect of different growth regulator and growing media on seed germination and physiological development of papaya seedlings (Carica papaya L.) cv. Madhubindu

\begin{tabular}{|c|c|c|c|c|c|c|c|c|c|c|c|c|c|c|}
\hline \multirow{2}{*}{ Treatments } & \multirow{2}{*}{$\begin{array}{l}\text { No. of } \\
\text { days } \\
\text { require } \\
\text { d for } \\
\text { first } \\
\text { germin } \\
\text { ation } \\
\end{array}$} & \multirow{2}{*}{$\begin{array}{c}\text { No. of } \\
\text { days } \\
\text { require } \\
\text { d for } \\
50 \% \\
\text { germin } \\
\text { ation } \\
\end{array}$} & \multicolumn{2}{|c|}{$\begin{array}{c}\text { Germination } \\
\text { percentage }\end{array}$} & \multicolumn{2}{|c|}{$\begin{array}{l}\text { Seed vigour } \\
\text { index-I }(\mathrm{cm})\end{array}$} & \multicolumn{2}{|c|}{$\begin{array}{l}\text { Seed vigour } \\
\text { index-II (g) }\end{array}$} & \multicolumn{2}{|c|}{$\begin{array}{l}\text { Dry weight of } \\
\text { shoot (g) }\end{array}$} & \multicolumn{2}{|c|}{$\begin{array}{l}\text { Dry weight of } \\
\quad \operatorname{root}(\mathrm{g})\end{array}$} & \multicolumn{2}{|c|}{$\begin{array}{l}\text { Root: shoot } \\
\text { ratio (g) }\end{array}$} \\
\hline & & & $\begin{array}{c}10 \\
\text { DAS }\end{array}$ & $\begin{array}{c}20 \\
\text { DAS }\end{array}$ & $\begin{array}{c}\text { 30 } \\
\text { DAS }\end{array}$ & $\begin{array}{c}45 \\
\text { DAS }\end{array}$ & $\begin{array}{c}\text { 30 } \\
\text { DAS }\end{array}$ & $\begin{array}{c}45 \\
\text { DAS }\end{array}$ & $\begin{array}{c}\text { 30 } \\
\text { DAS }\end{array}$ & $\begin{array}{c}45 \\
\text { DAS }\end{array}$ & $\begin{array}{c}\text { 30 } \\
\text { DAS }\end{array}$ & $\begin{array}{c}45 \\
\text { DAS }\end{array}$ & $\begin{array}{c}30 \\
\text { DAS }\end{array}$ & $\begin{array}{c}45 \\
\text { DAS } \\
\end{array}$ \\
\hline $\mathbf{G}_{1}$ & 8.66 & 10.88 & 58.77 & 81.00 & 1215 & 2533 & 79 & 140 & 0.58 & 0.95 & 0.38 & 0.76 & 0.66 & 0.81 \\
\hline $\mathbf{G}_{2}$ & 7.88 & 9.88 & 61.11 & 83.33 & 1373 & 2477 & 103 & 162 & 0.77 & 1.07 & 0.47 & 0.86 & 0.61 & 0.80 \\
\hline $\mathbf{G}_{3}$ & 7.55 & 9.44 & 77.00 & 87.00 & 1462 & 2579 & 114 & 214 & 0.77 & 1.40 & 0.53 & 1.04 & 0.68 & 0.76 \\
\hline $\mathbf{G}_{4}$ & 8.55 & 11.67 & 59.55 & 82.55 & 1308 & 2392 & 100 & 166 & 0.68 & 1.13 & 0.52 & 0.85 & 0.79 & 0.81 \\
\hline $\mathbf{G}_{5}$ & 8.33 & 10.66 & 57.44 & 83.11 & 1468 & 2730 & 126 & 200 & 0.79 & 1.35 & 0.71 & 1.05 & 0.90 & 0.91 \\
\hline $\mathbf{G}_{6}$ & 9.22 & 11.00 & 53.11 & 81.77 & 1518 & 2868 & 130 & 216 & 0.85 & 1.45 & 0.73 & 1.18 & 0.85 & 0.87 \\
\hline S.Em. \pm & 0.25 & 0.27 & 1.69 & 1.05 & 46.35 & 53.65 & 2.43 & 6.00 & 0.02 & 0.04 & 0.01 & 0.03 & 0.02 & 0.02 \\
\hline C.D. at 5\% & 0.72 & 0.78 & 4.85 & 3.01 & 132.9 & 153.8 & 6.97 & 17.21 & 0.06 & 0.11 & 0.04 & 0.08 & 0.06 & 0.05 \\
\hline $\mathbf{M}_{1}$ & 7.55 & 9.05 & 77.89 & 88.28 & 1679 & 2900 & 126 & 214 & 0.82 & 1.35 & 0.62 & 1.07 & 0.75 & 0.83 \\
\hline $\mathbf{M}_{2}$ & 9.77 & 12.89 & 45.61 & 77.16 & 1079 & 2219 & 88 & 151 & 0.64 & 1.09 & 0.49 & 0.85 & 0.77 & 0.83 \\
\hline $\mathbf{M}_{3}$ & 7.77 & 9.83 & 59.89 & 83.83 & 1415 & 2670 & 112 & 183 & 0.77 & 1.23 & 0.56 & 0.95 & 0.73 & 0.82 \\
\hline S.Em. \pm & 0.17 & 0.19 & 1.19 & 0.74 & 32.59 & 37.94 & 1.71 & 4.24 & 0.01 & 0.02 & 0.01 & 0.02 & 0.01 & 0.01 \\
\hline C.D. at 5\% & 0.51 & 0.55 & 3.43 & 2.12 & 94.02 & 108.8 & 4.93 & 12.17 & 0.04 & 0.08 & 0.03 & 0.06 & NS & NS \\
\hline C.V \% & 9.05 & 7.70 & 8.31 & 3.79 & 9.99 & 6.19 & 6.67 & 9.81 & 8.57 & 9.87 & 8.10 & 9.67 & 8.63 & 7.17 \\
\hline Interaction $\mathbf{G} \times \mathbf{M}$ & NS & Sig. & Sig. & Sig. & Sig. & Sig. & Sig. & Sig. & Sig. & Sig. & Sig. & Sig. & Sig. & Sig. \\
\hline
\end{tabular}


Table.2 Interaction effect of growth regulators and growing media on seed germination and physiological development of papaya seedlings (Carica papaya L.) cv. Madhubindu

\begin{tabular}{|c|c|c|c|c|c|c|c|c|c|c|c|c|c|}
\hline \multirow{2}{*}{$\begin{array}{c}\text { Treatment } \\
\text { combination }\end{array}$} & \multirow{2}{*}{$\begin{array}{c}\text { No. of } \\
\text { days } \\
\text { required } \\
\text { for } 50 \% \\
\text { germinati } \\
\text { on } \\
\end{array}$} & \multicolumn{2}{|c|}{$\begin{array}{c}\text { Germination } \\
\text { percentage }\end{array}$} & \multicolumn{2}{|c|}{$\begin{array}{l}\text { Seed vigour } \\
\text { index-I }(\mathrm{cm})\end{array}$} & \multicolumn{2}{|c|}{$\begin{array}{l}\text { Seed vigour } \\
\text { index-II (g) }\end{array}$} & \multicolumn{2}{|c|}{$\begin{array}{l}\text { Dry weight of } \\
\text { shoot (g) }\end{array}$} & \multicolumn{2}{|c|}{$\begin{array}{l}\text { Dry weight of } \\
\text { root }(\mathrm{g})\end{array}$} & \multicolumn{2}{|c|}{$\begin{array}{l}\text { Root: shoot } \\
\text { ratio (g) }\end{array}$} \\
\hline & & $\begin{array}{c}10 \\
\text { DAS }\end{array}$ & $\begin{array}{c}20 \\
\text { DAS }\end{array}$ & $\begin{array}{c}\text { 30 } \\
\text { DAS }\end{array}$ & $\begin{array}{c}45 \\
\text { DAS }\end{array}$ & $\begin{array}{c}30 \\
\text { DAS }\end{array}$ & $\begin{array}{c}45 \\
\text { DAS }\end{array}$ & $\begin{array}{c}30 \\
\text { DAS }\end{array}$ & $\begin{array}{c}45 \\
\text { DAS }\end{array}$ & $\begin{array}{c}\text { 30 } \\
\text { DAS }\end{array}$ & $\begin{array}{c}45 \\
\text { DAS }\end{array}$ & $\begin{array}{c}\text { 30 } \\
\text { DAS }\end{array}$ & $\begin{array}{c}45 \\
\text { DAS }\end{array}$ \\
\hline $\mathbf{G}_{1} \mathbf{M}_{1}$ & 9.33 & 73.33 & 82.00 & 1470 & 2472 & 93 & 156 & 0.72 & 1.06 & 0.42 & .83 & 0.58 & 0.78 \\
\hline $\mathbf{G}_{1} M_{2}$ & 13.66 & 40.33 & 75.00 & 872 & 2320 & 56 & 106 & 0.41 & 0.77 & 0.34 & 0.65 & 0.81 & 0.84 \\
\hline $\mathbf{G}_{\mathbf{1}} \mathbf{M}_{3}$ & 9.66 & 62.66 & 86.00 & 1302 & 2808 & 86 & 158 & 0.62 & 1.02 & 0.38 & 0.81 & 0.61 & 0.81 \\
\hline $\mathbf{G}_{2} \mathbf{M}_{1}$ & 9.00 & 80.00 & 88.67 & 1710 & 2523 & 105 & 186 & 0.70 & 1.17 & 0.49 & 0.92 & 0.70 & 0.78 \\
\hline $\mathbf{G}_{2} \mathbf{M}_{2}$ & 11.33 & 41.33 & 76.67 & 1125 & 2205 & 100 & 128 & 0.81 & 0.91 & 0.50 & 0.76 & 0.62 & .83 \\
\hline $\mathbf{G}_{2} \mathbf{M}_{3}$ & 9.33 & 62.00 & 84.00 & 1283 & 2704 & 104 & 172 & 0.82 & 1.14 & 0.42 & 0.90 & 0.51 & 0.80 \\
\hline $\mathbf{G}_{3} \mathbf{M}_{1}$ & 8.33 & 84.00 & 95.00 & 1661 & 2733 & 113 & 233 & 0.74 & 1.40 & 0.44 & 1.06 & 0.60 & 0.75 \\
\hline $\mathbf{G}_{3} \mathbf{M}_{2}$ & 11.00 & 67.00 & 77.00 & 994 & 2172 & 88 & 173 & 0.67 & 1.28 & 0.47 & 0.97 & 0.70 & 0.75 \\
\hline $\mathbf{G}_{3} \mathbf{M}_{3}$ & 9.00 & 80.00 & 89.00 & 1729 & 2833 & 142 & 234 & 0.91 & 1.53 & 0.69 & 1.10 & 0.76 & 0.77 \\
\hline $\mathbf{G}_{4} \mathbf{M}_{1}$ & 9.00 & 82.00 & 93.66 & 1659 & 3024 & 104 & 205 & 0.67 & 1.24 & 0.44 & 0.95 & 0.75 & 0.77 \\
\hline $\mathbf{G}_{4} \mathbf{M}_{2}$ & 15.66 & 39.33 & 73.00 & 947 & 1620 & 80 & 118 & 0.62 & 0.95 & 0.48 & 0.66 & 0.78 & 0.80 \\
\hline $\mathbf{G}_{4} \mathbf{M}_{3}$ & 10.33 & 56.66 & 81.00 & 1319 & 2533 & 115 & 175 & 0.77 & 1.21 & 0.65 & 0.96 & 0.85 & 0.87 \\
\hline $\mathbf{G}_{5} \mathbf{M}_{1}$ & 9.33 & 76.66 & 86.66 & 1731 & 3136 & 172 & 248 & 1.03 & 1.60 & 0.96 & 1.26 & 0.96 & 0.97 \\
\hline $\mathbf{G}_{5} M_{2}$ & 12.66 & 43.00 & 81.00 & 1257 & 2445 & 99 & 177 & 0.62 & 1.21 & 0.59 & 0.98 & 0.95 & 0.96 \\
\hline $\mathbf{G}_{5} M_{3}$ & 10.00 & 52.66 & 81.66 & 1416 & 2609 & 108 & 176 & 0.74 & 1.23 & 0.58 & 0.92 & 0.79 & 0.81 \\
\hline $\mathbf{G}_{6} M_{1}$ & 9.33 & 71.33 & 83.66 & 1841 & 3515 & 170 & 259 & 1.06 & 1.66 & 0.97 & 1.43 & 0.92 & 0.95 \\
\hline $\mathbf{G}_{6} \mathbf{M}_{2}$ & 13.00 & 42.66 & 80.33 & 1275 & 2553 & 102 & 203 & 0.72 & 1.43 & 0.55 & 1.10 & 0.77 & 0.79 \\
\hline $\mathbf{G}_{6} M_{3}$ & 10.66 & 45.33 & 81.33 & 1439 & 2536 & 117 & 186 & 0.77 & 1.26 & 0.67 & 1.03 & 0.86 & 0.89 \\
\hline S. Em. \pm & 0.47 & 2.93 & 1.81 & 80.29 & 92.93 & 4.21 & 10.39 & 0.03 & 0.07 & 0.02 & 0.05 & 0.03 & 0.03 \\
\hline C.D. at 5\% & 1.35 & 8.41 & 5.21 & 230.3 & 266.5 & 12.07 & 29.81 & 0.10 & 0.20 & 0.07 & 0.15 & 0.10 & 0.09 \\
\hline
\end{tabular}

Effect of growing media on seedling growth attributes

Media $\mathrm{M}_{1}$ [soil + cocopeat (1:1)] significantly recorded the maximum seed vigour index- I $(1679 \mathrm{~cm}$ and $2900 \mathrm{~cm})$, seed vigour index- II $(126 \mathrm{~g}$ and $214 \mathrm{~g})$, dry weight of shoot $(0.82 \mathrm{~g}$ and $1.35 \mathrm{~g})$, dry weight of root $(0.62 \mathrm{~g}$ and $1.07 \mathrm{~g})$ at 30 and $45 \mathrm{DAS}$, respectively as compared to rest of media.

This result was in close agreement with Kumawat et al., (2014) and Ramteke et al., (2015) in papaya when they used cocopeat as ingredients of growing media.

This might be attributed due to general improvement in the physical and chemical properties of the rooting medium (Dilip et al., 1994).
Interaction effect growth regulators and growing media on seedling growth attributes

Interaction effect of $\mathrm{G}_{6} \mathrm{M}_{1}$ [cow urine $10 \%$ dipping for 18 hours and soil + cocopeat (1:1)] recorded significantly the highest seed vigour index- I (1841 cm and $3515 \mathrm{~cm})$, dry weight of shoot (1.06 $\mathrm{g}$ and $1.66 \mathrm{~g})$, dry weight of root $(0.97 \mathrm{~g}$ and $1.43 \mathrm{~g})$ at 30 and 45 DAS, respectively and also recorded significantly the maximum seed vigour indexII (259 g) at 45 DAS as compared to rest of combinations. Whereas, the treatment combination $\mathrm{G}_{5} \mathrm{M}_{1}$ [cow urine $10 \%$ dipping for 12 hours and soil + cocopeat (1:1)] recorded significantly the highest seed vigour index- II (172 g) at 30 DAS and also recorded the significantly highest root: shoot ratio $(0.96$ $\mathrm{g}$ and $0.97 \mathrm{~g}$ ) at 30 and $45 \mathrm{DAS}$, respectively 
than rest of the combinations. These results were closely associated with the findings of Sutheesh et al., (2016) in sandal wood. It might be due to the cow urine contains physiologically active substances viz., growth regulators, nutrients (Josef and Nair, 1989) and trace elements (Munoz, 1988) and media provided better condition like aeration and porosity for proper growth and development of seedlings which helped to increase seed germination and height of the seedlings ultimately leads to increase seed vigour and dry weight of root and shoot of seedlings.

On the basis of the results obtained in this study, it is concluded that the growth regulators and growth media significantly influence the seed germination and seedling growth. The treatment combination $\mathrm{G}_{6} \mathrm{M}_{1}$ [cow urine $10 \%$ dipping for 18 hours and soil + cocopeat (1:1)] is found superior and most effective for better physiological development of papaya seedlings over the rest of the treatment combinations.

\section{Acknowledgement}

We are thankful to the Director of Research \& Dean PG Studies, Anand Agricultural University Anand, Head of the Department of Horticulture, Anand Agricultural University, Anand for providing necessary facilities for conducting the present investigation.

\section{References}

Ambica, S., and Balakrishnan, K. 2015. Enhancing germination and seedling vigour in cluster bean by organic priming. Scientific Research and Essays. 10(8): 298-301.

Ambika, S., Balakrishnan, K., and Sujatha, K. 2014. Enhancing the seed germination and vigour in coarse cereals by bovine urines. Journal of Agro ecology and Natural Resource Management. 1(2):
40-43.

Anjanawe, S.R., Kanpure, R. N., Kachouli, B. K., and Mandloi, D. S. 2013. Effect of plant growth regulators and growth media on seed germination and growth vigour of papaya. Annals of Plant and Soil Research. 15(1): 31-34.

Anonymous, 2016. Retrieved from https://en.m.wikipedia.org/wiki/gomutra Arvind, K.R., Patel, K. M., and Upadhyay, N. V. 2015. Effect of different growing media and containers on germination and establishments of seedlings of papaya (Carica papaya L.) cv. Madhubindu. Trends in Bio Sciences. 8(1): 227-235.

Bisla, S.S., Singhrot, R. S., and Chauhan, S. S. 1984. Effect of growing media on seed germination and growth of Ber. Haryana Journal of Horticulture Science. 13 (3/4): 118-122.

Deb, P., Das, A., Ghosh, S. K., and Suresh, C. P. 2010. Improvement of seed germination and seedling growth of papaya (Carica papaya L.) through different pre-sowing seed treatments. Acta Horticulture. 851: 313-316.

Dilip, M., Sudhakara, K., Santhoshkumar, A. V., Nazeema, K. K., and Ashokan, P. K. 1994. Effect of seed size, rooting medium and fertilizers on the growth of seedlings of silk cotton (Ceiba pentandra Linn.). Indian Journal of Forestry. 17(4): 293-300.

Edwards, C.A., 2009. The use of earthworm in the break down and management of organic waste. Earthworm Ecology. Pp.: 327-354.

Hasan, M.A., Manna, M., and Suresh, C. P. 2010. Standardization of growing media for seed germination in papaya. Abstract 2010. 7-28 FinalKrishiBangla.com. 11.

Joseph, 1989. Effect of seed hardening on germination and seedling vigour in paddy. Seed Research. 17(2): 188-190. 
Kamalam, J., and Rajappan, N. 1989. Effect of seed hardening on germination and seedling vigour in paddy. Seed Research. 17(2): 188-190.

Kumawat, R., Maji, S., Govind, and Meena, D. C. 2014. Studies on seed germination and seedling growth of papaya (Carica papaya L.) cv. Coorg Honey Dew as influenced by media and chemicals. Journal of Crop and Weed. 10(2): 281286.

Mandal, B., Dash, A. K., Mishra, N., Mishra, P. P., and Ray, M. 2015. Studies on the effect of media and growth regulating substances on seed germination of papaya. International Journal of Tropical Agriculture. 33(4): 2621-2623.

Mayer, A.M., and Mayber, A. P. 1963. The germination of seeds. MacMillan, New York. N. Y. Pp.: 236.

Munoz, A.M.., 1988. Increasing the vigour of rice seeds with trace element application. Arrazy, 37: 20-27.

Paleg, L., 1965. Physiological effects of gibberellins. Annual Review of Plant Physiology. 16: 291-322.

Panse, V.G., and Sukhatme, P. V. 1985. Statistical methods for agricultural workers. ICAR, New Delhi.

Patil, D.R., and Patil, M. N. 2010. Effect of seed treatment with $\mathrm{GA}_{3}$ and NAA on growth and yield of okra (Abmelmoschus esculentus L. Moench) cv. GO-2. Asian Journal Horticulture. 5(2): 269-272.

Patil, S.R., Somkamble, A. M., and Khobragade, H. M. 2012. Influence of some growth regulators on germination and seedling growth of rangpur lime under shade net house condition. Green Farming. 3(6): 494-497.

Ramteke, V., Paithankar, D. H., Ningot, E. P., and Kurrey, V. K. 2015. Effect of $\mathrm{GA}_{3}$ and propagation media on germination, growth and vigour of papaya cv. Coorg Honey Dew. International Quarterly Journal of Life Science. 10(3): 10111016.

Subramanian, A., 2005. Effect of Panchagavya on Escherchia coli in procured milk. Indian Veterinary Journal. 82: 799-800.

Sutheesh, V.K., Jijeesh, C. M., and Divya, T. P. 2016. Evaluation of organic and inorganic pre-treatments for better seed germination and seedling vigour in (Santalum album L.). Plant Archives. 16(1): 143-150.

Yahiro, M., 1979. Effects of seed pretreatments on the promotion of germination in papaya (Carica papaya L.). Memories of the Faculty of Agriculture. Kagoshima University. 15: 49-54.

\section{How to cite this article:}

Amit Desai, Ashwin Trivedi, Bharat Panchal and Velji Desai. 2017. Improvement of Papaya Seed Germination by Different Growth Regulator and Growing Media under Net House Condition. Int.J.Curr.Microbiol.App.Sci. 6(9): 828-834. doi: https://doi.org/10.20546/ijcmas.2017.609.102 